\title{
'Fortune' Mandarin Quality following Prestorage Water Dips and Intermittent Warming during Cold Storage
}

\author{
Mario Schirra \\ Consiglio Nazionale delle Ricerche, Istituto per la Fisiologia della Maturazione \\ e della Conservazione del Frutto delle Specie Arboree Mediterranee, Via Dei \\ Mille, 48-07100 Sassari, Italy
}

Maurizio Mulas

Istituto di Coltivazioni Arboree dell'Università di Sassari, Via De Nicola, 1 07100 Sassari, Italy

\section{Additional index words. chilling injury, Citrus reticulata, decay, metabolites}

\begin{abstract}
Freshly harvested 'Fortune' mandarins (Citrus reticulata Blanco) were dipped for 3 minutes in 25 or $52 \mathrm{C}$ water and then stored for 5 weeks at $2 \mathrm{C}$. Then, the fruit were or were not intermittently warmed at $10 \mathrm{C}$ for 3 days after each 4-day storage period. All fruit then were held at $20 \mathrm{C}$ for 1 week to simulate retail marketing. Chilling injury was more severe in fruit dipped in $25 \mathrm{C}$ water and stored at $2 \mathrm{C}$ than in fruit dipped in $25 \mathrm{C}$ water and stored under intermittent warming. The hot dip treatment significantly reduced the extent of damage during storage and the subsequent 1 week of holding at $20 \mathrm{C}$. The hot dip treatment reduced the incidence of fungal decay, especially during holding at 20C. Dip temperature and storage conditions slightly affected fruit physiological and quality characteristics. We conclude that prestorage hot dip treatments can be used to improve 'Fortune' mandarin storing qualities. Also, this practice may be combined with intermittent warming during cold storage, and it could help limit fungicide use in postharvest treatments.
\end{abstract}

'Fortune' is a mandarin-like hybrid of 'Clementine' and 'Dancy' tangerine that is appreciated for its agronomic characteristics, rich flavor, high-quality fruit, and late ripening (Young, 1986). Prolonging the marketing period of 'Fortune' mandarins through 6- to 8week cold storage would make it possible to obtain good prices for fruit of higher eating quality than for other late mandarins (Agabbio and Casu, 1983; Jackson et al., 1992).

However, 'Fortune' mandarins are sensitive to low field temperatures (Agustì and Almela, 1989; Bono et al., 1984) and are even more susceptible to chilling injury (CI) during 1 -month of cold storage at $<10 \mathrm{C}$. After 3 weeks of cold storage, severe pitting of flavedo develops (Duarte and Guardiola, 1993; Martinez-Jàvega et al., 1992; Martinez-Tellez and Lafuente, 1993). Consumers are demanding products with no chemical residues, and many researchers are involved in developing safe, nonpolluting procedures without compromising product defenses (Sharples, 1990).

The late ripening of 'Fortune' offers the possibility of it being marketed when other mandarins are going off the market. Our experiment was designed to extend mandarin

Received for publication 31 Jan. 1994. Accepted for publication 11 Nov. 1994. We have all contributed equally to this study. The cost of publishing this paper was defrayed in part by the payment of page charges. Under postal regulations, this paper therefore must be hereby marked advertisement solely to indicate this fact. storage life using cold storage preceded by a prestorage hot water dip treatment in conjunction with intermittent warming as nonchemical means to control postharvest decay.

\section{Material and Methods}

Commercially ripe $(1.13 \%$ of citric acid and $10.3 \%$ soluble solids) 'Fortune' mandarins [5 to $7 \mathrm{~cm}$ in diameter (maximum)] were harvested in Apr. 1993 at the experimental orchard of the National Research Council in Oristano (west central Sardinia, Italy, lat. $39^{\circ} 55^{\prime} \mathrm{N}$ ). Fruit were delivered to the laboratory immediately after harvest. Defective fruit (i.e., green, pitted, or wounded) were discarded. Sound mandarins were selected (120 to $150 \mathrm{~g}$ each) and grouped into two lots. Each lot contained 600 fruit. One lot was submerged for $3 \mathrm{~min}$ in $25 \mathrm{C}$ water; the other lot was submerged for $3 \mathrm{~min}$ in $52 \mathrm{C}$ water. After the hot-water treatment, each lot was divided into two subgroups, each containing 300 fruit. One subgroup was stored at $2 \mathrm{C}$ for 5 weeks without intermittent warming; the other subgroup was stored at $2 \mathrm{C}$ with intermittent warming at $10 \mathrm{C}$ for 3 days every 4 days. A 6- to 8-h equilibration time was necessary during warming and cooling. Relative humidity (RH) in the cold rooms was always $90 \%$ to $95 \%$. After 5 weeks of cold storage, the fruit were held one additional week at $20 \mathrm{C}$ and $75 \% \mathrm{RH}$ to simulate retail marketing conditions. Each 300-fruit subgroup contained three 50-fruit replications for external appearance observations and three 50 -fruit replications for chemical analyses.
At the end of cold storage and after the week of holding at 20C, fruit were inspected for CI and percentage of decay caused by mold. CI was rated visually on the following scale: $0=$ none; $1=$ slight $2=$ moderate; and $3=$ severe, depending on the extent of damage. To obtain a weighted average for a chilling index, the number of fruit in each CI rating was multiplied by the designated number and an average was taken (Eaks, 1980). Overall visual quality was evaluated by an informal test panel of three technicians using the following scale: $9=$ excellent, $7=$ good (fresh, limit of marketability), 5 = fair (fairly fresh, limit of edibility), $3=$ poor (old, not fresh). An average visual score was calculated. Three replications of 20 healthy fruit were randomly selected before the hot water dip, after cold storage, and after 1 week of storage at $20 \mathrm{C}$ to evaluate physiological behavior (respiration rate, endogenous ethylene production, and acetaldehyde and ethanol content in the juice) at 20C and internal quality characteristics [percentage of juice, total acidity (TA) as percentage of citric acid, total soluble solids (TSS) as ${ }^{\circ}$ Brix, and maturity index as the TSS : TA ratio]. Analyses were performed as previously described (Schirra, 1992).

Data were processed for analysis of variance by means of the MSTAT-C (Michigan State Univ. microcomputer program, 1991) software. A split-split-plot design was used, where dip temperature was the main plot, storage regime was the subplot, and the in-

Table 1. Influence of prestorage water-dip-temperature treatment and storage conditions on chilling injury rating and decay incidence on 'Fortune' mandarin after one additional week at $20 \mathrm{C}{ }^{2}$

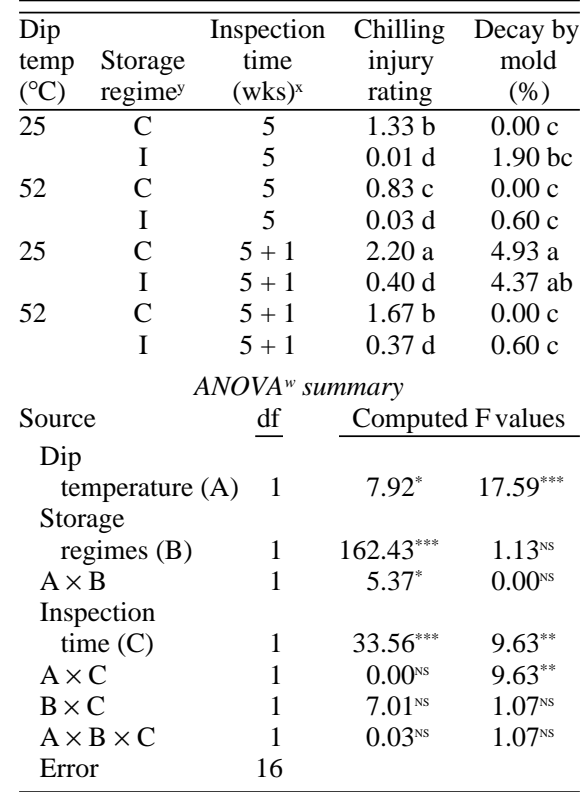

${ }^{\mathrm{z}}$ Mean separation by Duncan's multiple range test at $P \leq 0.05$.

${ }^{\mathrm{y}} \mathrm{C}=$ constantly at $2 \mathrm{C} ; \mathrm{I}=$ stored at $2 \mathrm{C}$ interrupted by 3 days at $10 \mathrm{C}$ every 4 days.

$\times 5=5$ weeks at $2 \mathrm{C} ; 5+1=5$ weeks at $2 \mathrm{C}$ plus 1 week at $20 \mathrm{C}$.

${ }^{\mathrm{w}} \mathrm{ANOVA}=$ analysis of variance.

ns, *, **, ****Nonsignificant or significant at $P \leq 0.05$, 0.01 , or 0.001 , respectively. 
spection time was the sub-subplot factor. Mean comparisons were performed using Duncan's multiple range test at $P \leq 0.05$.

\section{Results and Discussion}

Fruit dipped at $25 \mathrm{C}$ and stored continuously at $2 \mathrm{C}$ developed extensive CI compared to hot-dip-treated fruit during cold storage and holding at 20C. Conversely, fruit kept under intermittent warming exhibited a low incidence of CI and revealed minor differences in the $\mathrm{CI}$ index in relation to dip temperature (Table 1).

A low incidence of decay caused by mold (mainly Penicillium italicum Wehmer) occurred after 5 weeks of storage at constant temperature, without differences due to prestorage dips. Fruit maintained under intermittent warming also showed little decay $(<2 \%$ and $1 \%$ in those dipped in water at 25 or $52 \mathrm{C}$, respectively). Holding at $20 \mathrm{C}$ increased decay percentage in fruit dipped at $25 \mathrm{C}$ by $\approx 5 \%$ under both storage conditions; decay did not increase in hot-dip-treated fruit.

Compared to continuous storage at $2 \mathrm{C}$, intermittent warming significantly reduced the fruit respiration rate at $20 \mathrm{C}$ and endogenous ethylene concentration after 5 weeks of storage (Table 2).

Differences after holding, however, were not significant in most cases. The physiological response of fruit was only slightly affected by dip temperature during storage and after holding.

Internal quality attributes were affected by cold storage and subsequent holding, but differences due to storage regimes and dip temperature were negligible (Table 2).
Overall visual quality did not reveal important differences at the end of 5 weeks of storage (data not shown). After holding, however, fruit stored with intermittent warming were more turgid and had better appearance than controls.

In line with previous findings with other citrus cultivars (McDonald et al., 1991; Schirra and Mulas, 1993; Wild and Hood, 1989), our results confirm the effectiveness of prestorage hot dip treatment in reducing CI and decay of 'Fortune' mandarins. Intermittent warming improved this effectiveness considerably and seems to be promising in terms of consumer safety and environmental protection.

In regard to intermittent warming, the cycling of temperatures based on a period coinciding with the work week ( 4 days at $2 \mathrm{C}+3$ days at 10C) was arranged to facilitate management of the cycle and to increase the total high-temperature period. This treatment may have removed toxic or inhibiting substances that accumulate during chilling (Lyons, 1973).

\section{Literature Cited}

Agabbio, M. and M. Casu. 1983. Dodici cultivar di mandarino e mandarino simili a confronto. Frutticoltura 45(1):5-22.

Agustì, M. and V. Almela. 1989. El cultivo de la mandarina Fortune en España. Problemas y perspectivas. Fruticultura Profesional 25:3948.

Bono, R., L. Fernandez De Cordova, and J. Soler. 1984. Comportamiento de las cultivares 'Page', 'Fairchild', 'Freemont', 'Fortune' y 'Temple'. Levante Agricola 249/250:10-14

Duarte, A.M.M. and J.L. Guardiola. 1993. Factors affecting rind pitting in the mandarin hybrids 'Fortune' and 'Nova'. The influence of exogenous growth regulators. Intl. Symp. on Quality of Fruit and Vegetables. The influence of preand postharvest factors and technology, 20-24 Sept. 1993, Chania, Greece. (Abstr.)

Eaks, I.L. 1980. Effect of chilling on respiration and volatiles of California lemon fruit. J. Amer. Soc. Hort. Sci. 105:865-869.

Jackson, P.R., M. Agusta, V. Almela, and M. Juan. 1992. Tratamientos para mejorar la conservación en el arbol del fruto de la mandarina Fortune Levante Agricola 1:16-22.

Lyons, J.M. 1973. Chilling injury in plants. Annu. Rev. Plant Physiol. 24:445-466.

Martinez-Jàvega, J.M., C. Saucedo, and M.A. del Rio. 1992. Influence of storage temperature and coating on the keeping quality of 'Fortune' mandarins, p. 1102-1103. Proc. VII Intl. Citrus Congr., Acireale, Italy, 8-13 Mar. 1992.

Martinez-Tellez, M.A. and M.T. Lafuente. 1993. Chilling-induced changes in phenylalanine ammonia-lyase, peroxidase, and polyphenoloxidase activities in citrus tissues. Acta Hort. 343:257263.

McDonald, R.E., W.R. Miller, and T.G. McCollum. 1991. Thiabendazole and imazalil applied at $53 \mathrm{C}$ reduce chilling injury and decay of grapefruit. HortScience 26:397-399.

Schirra, M. 1992. Behaviour of 'Star Ruby' grapefruit under chilling and nonchilling storage temperatures. Postharvest Biol. Technol. 2:315327.

Schirra, M. and M. Mulas. 1993. Keeping quality of 'Oroblanco' grapefruit-type as affected by hot dip treatments. Adv. Hort. Sci. 7:73-76.

Sharples, R.O. 1990. Future directions for horticultural postharvest technology. Postharvest News \& Information 3:191-194.

Wild, B.L. and C.W. Hood. 1989. Hot dip treatments reduce chilling injury in long-term storage of 'Valencia' oranges. HortScience 24:109110

Young, R.H. 1986. Fresh fruit cultivars, p. 101-126. In: W.F. Wardowski, S. Nagy, and W. Grieson (eds.). Fresh citrus fruit. AVI, Westport, Conn.

Table 2. Influence of prestorage water-dip-temperature treatment and storage conditions on physiological and chemical attributes of 'Fortune' mandarin after 5 weeks of storage and after one additional week at 20C. ${ }^{2}$

\begin{tabular}{|c|c|c|c|c|c|c|c|c|c|}
\hline \multirow{2}{*}{$\begin{array}{l}\text { Dip } \\
\text { temp } \\
\left({ }^{\circ} \mathrm{C}\right) \\
\end{array}$} & \multirow[b]{2}{*}{$\begin{array}{l}\text { Storage } \\
\text { regime }^{\mathrm{y}}\end{array}$} & \multirow{2}{*}{$\begin{array}{l}\text { Inspection } \\
\text { time } \\
(\mathrm{wks})^{\mathrm{x}}\end{array}$} & \multirow{2}{*}{$\begin{array}{c}\text { Respiration } \\
\text { rate } \\
\left(\mathrm{mg} \mathrm{CO}_{2} / \mathrm{kg} \text { per } \mathrm{h}\right) \\
\end{array}$} & \multirow{2}{*}{$\begin{array}{l}\text { Endogenous } \\
\text { ethylene } \\
\text { (ppm) }\end{array}$} & \multicolumn{5}{|c|}{ Internal quality factors } \\
\hline & & & & & $\begin{array}{c}\text { Acetaldegyde } \\
(\mathrm{mg} / 100 \mathrm{ml})\end{array}$ & $\begin{array}{c}\text { Ethanol } \\
(\mathrm{mg} / 100 \mathrm{ml})\end{array}$ & $\begin{array}{c}\text { TSS } \\
\left({ }^{\circ} \text { Brix }\right)\end{array}$ & TA & TSS : TA \\
\hline Contr & & 0 (harvest) & 25.5 & 0.01 & 0.32 & 22.4 & 10.3 & 1.13 & 9.2 \\
\hline \multirow[t]{2}{*}{25} & $\mathrm{C}$ & 5 & $11.3 \mathrm{c}^{\mathrm{w}}$ & $0.04 \mathrm{~b}$ & $0.52 \mathrm{ab}$ & $27.0 \mathrm{c}$ & $10.3 \mathrm{a}-\mathrm{d}$ & $1.01 \mathrm{a}$ & $10.3 \mathrm{~b}$ \\
\hline & I & 5 & $5.7 \mathrm{~d}$ & $0.01 \mathrm{e}$ & $0.42 \mathrm{~b}$ & $27.1 \mathrm{c}$ & $9.7 \mathrm{~cd}$ & $0.94 \mathrm{~b}$ & $10.2 \mathrm{~b}$ \\
\hline \multirow[t]{2}{*}{52} & $\mathrm{C}$ & 5 & $11.5 \mathrm{c}$ & $0.05 \mathrm{a}$ & $0.46 \mathrm{ab}$ & $22.8 \mathrm{c}$ & $9.4 \mathrm{~d}$ & $0.93 \mathrm{bc}$ & $10.1 \mathrm{~b}$ \\
\hline & I & 5 & $5.7 \mathrm{~d}$ & $0.01 \mathrm{e}$ & $0.44 b$ & $27.9 \mathrm{c}$ & $9.9 \mathrm{~b}-\mathrm{d}$ & $0.93 \mathrm{bc}$ & $10.6 \mathrm{~b}$ \\
\hline \multirow[t]{2}{*}{25} & $\mathrm{C}$ & $5+1$ & $15.5 \mathrm{~b}$ & $0.02 \mathrm{~d}$ & $0.53 \mathrm{ab}$ & $60.8 \mathrm{ab}$ & $10.8 \mathrm{a}-\mathrm{c}$ & $0.83 \mathrm{~d}$ & $12.9 \mathrm{a}$ \\
\hline & I & $5+1$ & $14.8 \mathrm{bc}$ & $0.02 \mathrm{~d}$ & $0.52 \mathrm{ab}$ & $53.7 \mathrm{~b}$ & $9.9 \mathrm{~b}-\mathrm{d}$ & $0.82 \mathrm{~d}$ & $12.1 \mathrm{a}$ \\
\hline \multirow[t]{3}{*}{52} & $\mathrm{C}$ & $5+1$ & $13.1 \mathrm{bc}$ & $0.02 \mathrm{~d}$ & $0.46 \mathrm{ab}$ & $60.0 \mathrm{ab}$ & $11.4 \mathrm{a}$ & $0.87 \mathrm{~cd}$ & $13.1 \mathrm{a}$ \\
\hline & I & $5+1$ & $20.8 \mathrm{a}$ & $0.03 \mathrm{c}$ & $0.56 \mathrm{a}$ & $63.7 \mathrm{a}$ & $10.9 \mathrm{ab}$ & $0.88 \mathrm{~cd}$ & $12.4 \mathrm{a}$ \\
\hline & & & \multirow{2}{*}{\multicolumn{7}{|c|}{ Computed $\mathrm{F}$ values }} \\
\hline \multicolumn{2}{|c|}{ Source } & $\mathrm{df}$ & & & & & & & \\
\hline \multicolumn{2}{|c|}{ Dip temperature (A) } & $\overline{1}$ & $1.55^{\mathrm{Ns}}$ & $2.58^{\mathrm{Ns}}$ & $0.42^{\mathrm{Ns}}$ & $15.50^{* *}$ & $0.88^{\mathrm{Ns}}$ & $0.00^{\mathrm{Ns}}$ & $0.29^{\mathrm{Ns}}$ \\
\hline \multicolumn{2}{|c|}{ Storage regimes (B) } & 1 & $2.09^{\mathrm{Ns}}$ & $27.84^{* * *}$ & $3.22^{\mathrm{Ns}}$ & $2.18^{\mathrm{Ns}}$ & $2.24^{\mathrm{Ns}}$ & $1.89^{\mathrm{Ns}}$ & $0.54^{\mathrm{Ns}}$ \\
\hline \multicolumn{2}{|c|}{$A \times B$} & 1 & $6.84^{*}$ & $0.47^{\text {Ns }}$ & $13.16^{* *}$ & $28.75^{* * * *}$ & $2.45^{\mathrm{Ns}}$ & $2.23^{\mathrm{vs}}$ & $0.24^{\mathrm{Ns}}$ \\
\hline \multicolumn{2}{|c|}{ Inspection time (C) } & 1 & $93.56^{* * * *}$ & $0.47^{\mathrm{Ns}}$ & $16.69^{* * * *}$ & $248.94^{* *}$ & $15.48^{* *}$ & $54.03^{* * * *}$ & $47.31^{* * * *}$ \\
\hline \multicolumn{2}{|c|}{$A \times C$} & 1 & $1.09^{\mathrm{Ns}}$ & $1.32^{\mathrm{vs}}$ & $2.22^{\mathrm{Ns}}$ & $0.30^{\mathrm{Ns}}$ & $5.77^{*}$ & $11.60^{* *}$ & $0.02^{\mathrm{Ns}}$ \\
\hline \multicolumn{2}{|c|}{$\mathrm{B} \times \mathrm{C}$} & 1 & $34.98^{* * *}$ & $50.58^{* * *}$ & $16.07^{* * *}$ & $18.65^{* * *}$ & $1.32^{\mathrm{Ns}}$ & $1.03^{\mathrm{Ns}}$ & $2.03^{\mathrm{Ns}}$ \\
\hline \multicolumn{2}{|c|}{$\mathrm{A} \times \mathrm{B} \times \mathrm{C}$} & 1 & $7.54^{*}$ & $1.32^{\mathrm{Ns}}$ & $1.59^{\mathrm{Ns}}$ & $0.17^{\mathrm{Ns}}$ & $0.53^{\mathrm{Ns}}$ & $0.80^{\mathrm{ss}}$ & $0.09^{\mathrm{Ns}}$ \\
\hline \multicolumn{2}{|c|}{ Error } & 16 & & & & & & & \\
\hline
\end{tabular}

${ }^{2}$ Harvest data is only included to provide a comparison to the other measurements.

${ }^{\mathrm{y}} \mathrm{C}=$ constantly at $2 \mathrm{C} ; \mathrm{I}=$ interrupted by 3 days at $10 \mathrm{C}$ every 4 days.

$\times 5=5$ weeks at $2 \mathrm{C} ; 5+1=5$ weeks at $2 \mathrm{C}$ plus 1 week at $20 \mathrm{C}$.

wMean separation by Duncan's multiple range test at $P \leq 0.05$.

"ANOVA $=$ analysis of variance.

Ns,,$* * * * * *$ Nonsignificant or significant at $P \leq 0.05,0.01$, or 0.001 , respectively. 